\title{
A LUZ DAS CIDADES SOMERXIDAS
}

\author{
César Antonio Molina
}

Casa del Lector

Fundación Germán Sánchez Ruipérez

doi: 10.17075/mucnoc.2014.001 

Forcadela, M. / T. López / D. Vilavedra (coords.) (2014): Mil e un cunqueiros. Novas olladas para un centenario, Santiago de Compostela, Consello da Cultura Galega. doi:10.17075/mucnoc.2014. pp. 19-48

Moitas grazas por permitirme inaugurar este congreso sobre o escritor galego máis importante do século xx e a quen coñecín dun xeito máis persoal desde os anos sesenta.

Dividín a miña intervención en dúas partes. Na primeira, contarei precisamente algunhas anécdotas da nosa relación. Na segunda, centrareime nas miñas lecturas da súa poesía.

Durante os anos sesenta, cando eu era un neno, Cunqueiro, ao longo do ano, desprazábase varias veces á Coruña desde Vigo, para dar unhas conferencias na Asociación Cultural Iberoamericana (a ACI), na que eran directivos dous dos seus mellores amigos: o poeta Miguel González Garcés e o meu tío Antonio. Un día encomendáronme recollelo no café Galicia, no Cantón Grande, e desde entón esta tarefa realizábaa dúas ou tres veces por ano durante esa década. Cunqueiro sempre chegaba no mesmo taxi despois de almorzar, saudaba os conferenciantes e, colléndome pola caluga coa súa enorme man de xogador de frontón, arrastrábame, a paso firme, camiño da casa do meu tío, en Porta de Aires. Se camiñabamos cara á rúa Real, detínase na Librería Arenas para falar co seu dono, Fernando, sobre novidades e sobre os libros de seu. Se atravesabamos os xardíns do invicto almirante Méndez Núñez (o Recheo), desprazabámonos polo porto entre os pasaxeiros e as grúas que cargaban cara ao edificio da Aduana, por entre os vultos dos viaxeiros e emigrantes a América nos últimos transatlánticos.

A Cunqueiro cegábao a luz que se reflectía nas augas daqueles espigóns e dicía que lle lembraban os pintados por Claudio de Lorena. Tamén quería aquela luz tan característica que reverberaba contra as cristaleiras das galerías. Detínase, apoiaba o seu pe dereito nos «norais de ferro amarrados e bisbaba como ausente: «Esta luz aínda non foi captada en ningún cuadro. É a luz das cidades sumerxidas».

Cunqueiro non falaba moito e cando o facía, coa súa voz profunda e remota de pozo desecado, xamais te miraba directamente á cara.

A cidade vella atravesabámola sempre en dúas direccións. Cando iamos cara á Porta de Aires, subiamos pola igrexa de Santiago para comprobar se aínda as esta- 
tuas románicas de san Xoán e san Marcos sostiñan sobre as súas cabezas aqueles libros que o soportaban todo fronte ao pazo de dona Emilia Pardo Bazán. Despois entrabamos por entre as sombras pechadas da praza de Azcárraga coa súa fonte dos desexos manando lágrimas insignificantes. Bordeando o costado do antigo Palacio do ilustrado Cornide, chegabamos ao piso do meu tío. Despois dunhas pequenas ablucións e apenas un lixeiro descanso, saïamos co tempo suficiente para realizar ese segundo percorrido antes da súa conferencia.

Esta segunda peregrinación comeza na Colexiata de Santa María do Campo, onde Cunqueiro se detiña extasiado pola Epifanía esculpida no tímpano románico da porta principal cara ao cruceiro da praza. Fascinábao esa insólita escena oriental dos Reis Magos cos seus presentes, xunto cun gran castelo moi semellante a unha torre de Babel. Imaxe que debeu de ser a primeira que viu Ramón Menéndez Pidal, que naceu xusto nunha casa do lado. Empurrando o portón de madeira do templo, Cunqueiro atravesábao dicindo: «Agora honraremos os señores do tempo pasado». Había moitas tumbas, mais el sempre ía cara a unha que se atopaba á dereita do magnífico altar maior de prata custeado polos mareantes. Poñía a súa man dereita aberta de par en par sobre a fría pedra e non a retiraba até que remataba de recitar algo semellante a isto:

¿Qué levas peleriño de Palmeiría?

Levo froles d'amigo para Santa María.

Moitas veces vino facer esta mesma operación sen reparar en quen podería ser o propietario daquel asentamento. Resultábame todo tan misterioso, que me negaba a desfacer aquel feitizo. E non só non se desfixo, senón que se acrecentou cando, tempo despois, descubrín que aquela man se apoiaba sobre os restos do Señor de Andeyro, cuxo corazón, segundo a lenda, fora trepanado por coitelos emboscados, ao ser descuberto no leito da raína viúva portuguesa, dona Leonor.

Cunqueiro, nalgúns textos, imaxina este nobre galego ao servizo de Portugal, no século XIV, como peregrino palmeiro, é dicir, dos que viaxaran a Xerusalén e trouxeran para a igrexa de Santa María do Campo unha xerra de azucenas coas súas armas, por iso aqueles versos. Na praza das Bárbaras, detínase cara á lápida da entrada do convento, ollando como san Miguel co dragón pesaba unha alma fronte á mirada protectora de Santiago aos seus peregrinos. Facíao atravesar na punta do pé o meu colexio dos Dominicos e ocultármonos nos soportais do 
xardín de san Carlos, antes de subir á Casa da Cultura, na que era bibliotecario Garcés, para dar alí a súa conferencia. Adiantábase por este patio sobre o mar e detínase fronte a aérea e romántica tumba de Sir John Moore, que o emocionaba máis por ser o amante de Lady Stanhope que pola súa gloriosa fazaña de perdedor. (Aquela dama que para esquecer a súa dor se perdeu en África mercando soños de amor co defunto e novo xeneral). Nas conferencias de Cunqueiro escoitei falar por vez primeira de Novalis e os seus amores incestuosos, de Heine, Keats, Shelley, Hölderlin, Kleist, Dante, Elliot, Valéry, Vicente Risco, Valle-Inclán ou Manoel Antonio, así como de Bizancio, Roma, Xerusalén, dos cabaleiros da Táboa Redonda, de Merlín ou de Hamlet. Non coñecía nada, e moitos anos tiveron que pasar para que algo percibise, mais non sería o mesmo sen aquelas tardes de lazarillo.

Cada vez que nos atopabamos, Cunqueiro traíame algúns dos seus libros dedicados coa promesa de que os gardase, mais que xamais os lería. Un día regaloume o Enrique de Ofterdingen; outro, entramos na antiga librería La Poesía, na estreita de Santo André, para mercarme un exemplar das Odas ao vento do Oeste e outros poemas, de Shelley, que rematabamos de ollar na vitrina, e, finalmente, noutra ocasión apareceu cos Himnos á noite.

Cando intuíu as miñas inclinacións literarias, desaconselloumas pola súa ingratitude e recomendoume, como home de orde que era, ser notario ou rexistrador, profesións máis honorables e seguras. Era un grande escéptico ao que traizoaba a súa vehemencia por todo o que relataba.

Meses despois de que lle desen o Premio Nadal por Un hombre que se parecía a Orestes, regresou á Coruña para dar outra das súas conferencias. Espereino, coma sempre, no Galicia. Tiña a súa novela subliñada e varias preguntas escritas para facerlle unha entrevista para unha revista escolar que se chamaba Nova xente. Cunqueiro non disimulou o seu desgusto pola miña desobediencia, concluíu rapidamente a charla e saímos a todo correr por algunhas das habituais rúas da vella Marineda. Despois acudira un par de veces na mińa axuda. Unha, cando lle comentaron que a mińa imaxinación non se correspondía de forma literal coas traducións de latín e grego para acceder á Universidade. Quedou entusiasmado coa miña ousadía literaria e foi mesmo falar persoalmente cos seus vellos amigos catedráticos e interceder no meu favor. 
A outra ocasión presentouse cando asinou, no Faro de Vigo, a primeira crítica sobre o meu libro de poemas, Épica, baixo o seu pseudónimo máis querido, Álvaro Labrada.

Estes paseos interrompéronse definitivamente na década seguinte, cando marchei a estudar Dereito a Santiago. Viaxei para velo en numerosas ocasións a Vigo, ao seu piso da rúa Marqués de Valladares, e coincidimos nos axitados anos estudantís de finais do franquismo, aínda que algo menos na Coruña.

Cando estaba gravemente enfermo, acudín no seu derradeiro Nadal para visitalo a Vigo. Pouco despois víao por derradeira vez en Madrid, no hospital, onde as diálises lle eran cada vez máis penosas. Charlamos moitísimo, aínda que xamais lembramos aqueles tempos e, no entanto, ao despedirme, cando xa abría a porta, díxome co seu sorriso retranqueiro: «Non deixes de darlle a man ao Señor de Andeyro".

\section{ÁLVARO CUNQUEIRO, VOLVER Á IDADE DOURADA}

A pesar de que a obra literaria de Álvaro Cunqueiro transcendeu polo seu extraordinario labor como narrador, tanto en galego como en castelán, nela sempre estivo latente un amplo e importante substrato poético. Non en van antes de que comezasen a xurdir as súas novelas dun xeito continuado ao longo da década dos anos cincuenta (Merlín e familia e outras historias, Vigo, 1955), despois dunha breve paréntese composta por outros libros de narracións curtas (San Gonzalo, Madrid, 1945; Balada de las damas del tiempo pasado, Madrid, 1945), e conseguise premios tan destacados naqueles anos como o da Crítica, en 1959, polas Crónicas do Sochantre, o Nadal, en 1968, cun Home que se parecía a Orestes, xa dera a coñecer unha boa parte da súa obra poética.

$\mathrm{Na}$ revista Escritos, lembraba a súa primeira publicación. Era un artigo titulado «Benvida a Xosé Ramón Santeiro», que apareceu nas follas de Vallibria, no ano 1928. Nel contaba as súas primeiras experiencias como lector: «Chegaba a veranear a Mondoñedo, dende Madrid, o fino poeta José Ramón Santeiro. Traía as novidades para min, literalmente, unha nova luz: os libros de Alberti, Cernuda, Lorca, Guillén, Salinas... ¡Que inmensa borracheira de poesía no bosque de Silva, á sombra dos plátanos, como nos diálogos platónicos!». Un lector de poesía 
castelá e tamén galega. Máis adiante, engade, non podía esquecer aquel verso de Manoel Antonio, «xurde baixo os pés o ronsel da vila natal». Álvaro Cunqueiro foi sempre un poeta que invadiu o campo da novela intercomunicando ambos os dous xéneros até fundilos nun estilo de seu e orixinal. Pero non só ao campo da prosa transcendeu o seu xeito peculiar de ver e interpretar o mundo por medio da palabra, senón tamén na súa curta pero frutífera actividade como autor teatral deixou esa pegada nunha peza mestra, $O$ incerto señor don Hamlet, principe de Dinamarca.

Mais se ben Cunqueiro continuou cultivando a poesía, a publicación desta foise dilatando até tal punto que moitas veces foi dado por fenecido como poeta, se non fose porque de cando en vez nos sorprendía coa edición de inéditos en separatas ou en revistas de creación galegas ou españolas.

Cales foron as razóns para esta automarxinación poética? No ano 1932, en Santiago de Compostela, publicado pola editorial Nós, aparecía o seu primeiro poemario: Mar ao Norde. Un ano despois, Cantiga nova que se chama Riveira e Poemas do si e non. O primeiro destes dous últimos, editado pola importante revista Resol. A Guerra Civil interrompe estas actividades, que se verán continuadas en 1940 con outro novo libro de poemas, pero esta vez en castelán, Elegías y canciones.

A contenda impediu que Álvaro Cunqueiro seguise avanzando na experimentación das vangardas e, á vez, produciríalle máis adiante dous desenganos. Por unha parte, a inviabilidade dunha estética imposta polos vencedores —entre os que se atopaba- e, pola outra, a mesma repulsión cara aos canons da nova literatura social que comezaba a nacer como resultado dunha incitante necesidade sociopolítica.

Cunqueiro comprendeu que a única posibilidade de sobrevivir culturalmente era a partir da fantasía, da imaxinación, da outra realidade, símbolo evidente de moitas insatisfaccións persoais e colectivas. Dalgún xeito rachou temporalmente con ese pasado, entregouse de cheo a un novo xénero literario, sen por iso esquecer as súas orixes. Con respecto ao seu abandono da actividade teatral, el mesmo dixera:

É unha estupidez escribir teatro se non vai ser representado. Escribín $A$ noite vai como un rio, porque me aseguraron que sería representada. $\mathrm{O}$ teatro non é para lelo, senón para 
oílo e velo sobre un escenario. En Galicia a actividade teatral sempre estivo postergada, e, ademais, tamén o tipo de teatro que eu facía non estaba de acordo coas correntes do momento. O Hamlet foi outra cousa, diferente, déralle moitas voltas á traxedia de Shakespeare e un día veume á cabeza unha especie de revelación.

A súa obra poética está composta por cinco libros en galego e un en castelán, ademais de abundantes poemas soltos publicados en numerosas revistas e xornais, fundamentalmente no Faro de Vigo durante a época en que estivo como director.

No primeiro tomo da Obra en galego completa estaban Mar ao Norde, Cantiga nova que se chama Riveira, Poemas do si e non e Dona do corpo delgado. Cantiga nova tivo unha segunda edición no ano 1957, con varios poemas máis. Este primeiro tomo incluía un novo libro inédito na súa totalidade, aínda que parcialmente coñecido polas súas esporádicas publicacións de poemas soltos. Herba aqui ou acolá é o seu título, e no libro hai grupos de poemas que nun principio pertenceron a outros proxectos de libros denominados provisionalmente: Eu son, Retorno de Ulises ou Crónica da derrota das nacións. Sen dúbida, Herba aqui ou acolá devolvíanos a un poeta na madurez da súa expresión e da súa reflexión. Como narrador, Álvaro Cunqueiro foi bilingüe e no xornalismo empregou con maior frecuencia o castelán; pero na poesía e no teatro, o galego era algo profundo e consubstancial. Con todo, na inmediata posguerra, publicou o seu único poemario en castelán, Elegías y canciones, e algo tan efémero como os seus poemas soltos en encomio dos nacionais e un dos famosos sonetos incluído en Corona de sonetos a José Antonio. A súa fidelidade á lingua natal e á súa cultura queda reflectida no epitafio que nos meses finais da súa existencia escribiu para que fose colocado sobre a súa tumba: «Eiquí xaz alguén que coa súa / obra fixo que Galicia durase / mil primaveras máis».

O pensamento poético de Cunqueiro pode resumirse na «Poética» que escribiu para a separata que lle dedicou a revista Atlántida da Coruña en 1954:

Non pretendín xamais ser un poeta inspirado e luminoso. Cos meus propios poemas intentei explicar a min mesmo que cousa é a poesía. Unha longa e esperanzada impaciencia é a miña actitude ante a creación poética.

Non concibo un poema que non dependa, en última instancia, da boca humana que o di. Recoñezo, pois, á poesía unha esencial e ineludible impureza. Con Rimbaud creo que o poeta rouba lume: «Se o que trae de abaixo ten forma, dá forma; se informe, dá o informe». 
Creo no encantamento polas palabras como a serpe cre na frauta, e este xogo de aprendiz de bruxo é, quizais, á parte unha violenta nostalxia e unha confortadora melancolía, a razón pola cal os meus poemas foron escritos e publicados.

Ao longo de todo o primeiro cuarto de século, a prensa literaria en Galicia tivo unha actividade moi destacada a través de publicacións como Alfar, Ronsel, Resol, Yunque, Nós e a mesma $A$ Nosa Terra, entre outras, en moitas das cales habería de colaborar con poemas seus e traducións Álvaro Cunqueiro. El mesmo, nos anos 1932 e 1933, creou e dirixiu dúas revistas, Galiza e Papel de cor. A primeira era unha folla de poesía nova. Nela colaboraron poetas como Aquilino Iglesia Alvariño, Fermín Bouza Brey, Luís Pimentel, Carballo Calero, ademais de Bal y Gay, Castelao, Francisco Fernández del Riego, Vicente Risco, Otero Pedrayo, etc. Tamén o fixo o propio Cunqueiro con poemas que non se volveron publicar. Papel de cor incluía no seu número unha "Elexía a Manoel Antonio», de Cunqueiro e, nos números seguintes, colaboracións de Aquilino Iglesia Alvariño e Carballo Calero.

Elegías y canciones aparecía en 1940. Ao final do mes, anunciábase que eran os primeiros versos do autor en castelán. Foron escritos ao longo dos anos 1934, 1935 e 1936. Levaba un áxil e premonitorio prólogo de Euxenio Montes. Elegías y canciones xamais volveu ser reeditado. $\mathrm{O}$ mesmo autor deitou sobre el o silencio. "Teño un certo pudor pola poesía». $\mathrm{O}$ volume está dividido en varias partes: «Elegías, canciones» e «Favorable prisión del sueño». Nesta última sección é onde se atopan catro poemas autotraducidos da súa primeira etapa en galego. $\mathrm{O}$ último do libro, «Nun álbun», incorporaríase arrancado ao poema cinco, «Ela», do libro Poemas do si e non, coa supresión de dous versos para readaptalo. O número cinco de Elegías y canciones corresponde ao poema seis de «Illa», segunda parte de Mar ao Norde, que nun principio dedicara a Ricardo Carballo Calero. Este poema é una autotradución exacta do poema galego primitivo. O número seis corresponde ao titulado "Hai unha illa loubada", de Cantiga nova que se chama Riveira. Presenta na súa versión en castelán algunhas modificacións e variantes non moi salientables. $\mathrm{O}$ número sete é o poema «Na nao do mar laranxa», incluído tamén en Cantiga nova que se chama Riveira. É unha versión fiel, aínda que este último aparecía con dous versos máis.

En Elegías y canciones, nun principio atopábase unha intención temporal de rachar coa súa etapa anterior e buscar novos camiños que pensaba que podían 
proporcionarlle o emprego do, por aquel entón, único idioma oficial e recoñecido. Estilisticamente, é unha poesía diferente da anterior e tamén o é na súa intención. Elexías e cancións tampouco se inscribe demasiado no quefacer dos poetas españois de posguerra, a excepción nuns poucos matices de ton relixioso. Este breve grupo atópase xunto baixo a epígrafe de «Favorable prisión do sono». Sitúanse nese arraigamento do relixioso na poesía, que fora aparecendo ao longo da década dos anos trinta. Fiel reflexo deste interese foron as numerosas antoloxías de poesía relixiosa, entre as que destacaría a de Ángel Valbuena Prat, de 1940, e a Suma poética, de José María Pemán e Miguel Hierro, así como o cultivo con maior ou menor intensidade realizado por Luis Felipe Vivanco, Luis Rosales ou Leopoldo Panero, entre outros moitos.

Se o relixioso abarca unha parte en Elegias y canciones, hai unha preocupación metafísica máis ampla. A presenza da morte, a pasaxe do tempo. A permanencia do amor como consolo efémero ofrécenos as primeiras pistas para recoñecer o Cunqueiro que aparecerá con posterioridade a Dona do corpo delgado. A primeira elexía, como todas as outras, aparece dunha idea xeral do poeta desde a súa interioridade, desde a súa reflexión persoal, desde a meditación do porqué da súa existencia como home e tamén como creador. A medida que avanza o poema pasa a un primeiro plano a inquietude esencial pola temporalidade. A primeira elexía expresa tamén a nostalxia (morriña) do distanciamento xeográfico, que non é máis que a relación simbólica do seu afastamento da mocidade e da infancia vivida no espazo dunha cidade: «¡Tú, viejo viento del Norte, / y tú, vieja ciudad amorosa! / Deseo cruzarme en vuestras esquinas, / los labios dulcemente decorados de silenciosas sonrisas».

A segunda elexía continúa incidindo nesta nostalxia. Mais o poeta intenta universalizala. No entanto, no catálogo de obxectos animados e inanimados que acumula, existe unha inconsciente obsesión por permanecer á flor de terra. Ante o paso do tempo e o nacemento dos recordos que o testemunan, céntrase en aprender o tempo pasado: “¡Oh ciudad! ¡Oh naranja! ¡Oh ceniza! / qué ovillo de seda u oro disparate / qué lengua o en qué consuelo destruirte / qué tijera afilar, o, silenciosamente / volver a la dorada edad, y en las columnas / clavarse con espadas y con hiedras».

$\mathrm{O}$ amor é un consolo da carne e, coma ela, efémero. Na cuarta elexía hai un verso que di: "Deja, déjame mi difunta suave...». Apoiándose na natureza, 
na paisaxe, no transcorrer das estación anuais, nos obxectos cotiáns, Cunqueiro configura toda unha metafísica da conciencia. Aplicando unha frase de Gaston Bachelard, o espello do exterior obrígao a lanzar o seu ser fóra, lanzalo ao mundo. E este mundo tan grande é simultaneamente particular e profundo. Na quinta elexía, como final, non podía menos que suxerirse o tema da despedida. A despedida supón a entrega a esa incerteza que provoca a situación de tránsito entre o palpable e visible cara ao descońecido. O poeta moi poucas veces pode intuílo no mundo terreal, aínda que, se cadra, a súa función máis importante está precisamente en saber captar eses instantes. $\mathrm{O}$ anxo, coma en Rilke —ou en plural—en Cunqueiro, son os compañeiros que auxilian no tránsito dun mundo ao outro.

A primeira elexía a Manoel Antonio, escrita en 1940, ten un significado moi especial. $\mathrm{O}$ recońecemento e homenaxe a un poeta que no seu momento pasou moi inadvertido. Transitaba, e aínda o faría ao longo de moitos anos, polos camiños do esquecemento se non fose pola publicación do tomo I da súa obra completa. Esta homenaxe é un recordo implícito á poesía galega e ás vangardas, ás cales sentimental e visceralmente sempre foi fiel. Cunqueiro, nas elexías, demostraba ser un magnífico cultivador do verso longo, que neste libro case roza o salmo.

Catro son as cancións e catro seres da fauna son os elixidos. O reiseñor, o cervo, a pomba e a laverca. Cada un deles sérvelle de desculpa ao poeta para evocar un estado de ánimo. A soidade e o silencio que se confunden coa autocontemplación, a pureza en unión case panteísta coa natureza e a liberdade. A diferenza do seu posible referente rilkeano, estas elexías e cancións de Cunqueiro teńen unha ansia de esperanza. Rilke compuxéraas case ao final da súa vida, e a escuridade e a desesperanza son máis evidentes. Hai tamén certo resaibo romántico moi de Novalis («Enrique de Ofterdingen» era un dos relatos preferidos polo mindoniense, quen sentía tamén unha gran fascinación pola biografía persoal e literaria do escritor alemán) e Heine e, por suposto, o gran descubrimento de Hölderlin, de quen sería un dos primeiros tradutores a unha lingua española.

O Cunqueiro de Elegías y canciones é un ser vivo, con moitas dúbidas, na plenitude da súa mocidade. Confía nos recursos das forzas naturais aínda nun estado primixenio, nun cosmos ao que, coma Rilke, converte en patria poética e vital.

Jean Cocteau afirmaba que un poema debería perder todas as cordas que o reteñen no que o motiva, e engadía: «Cada vez que o poeta corta unha de elas, o seu corazón latexa. Cando corta a derradeira, o poema desprende, ascende só 
como un globo, belo en si e sen ningún lazo coa terra». Este primeiro libro de Álvaro Cunqueiro en certa medida segue a fórmula invocada por Cocteau. Partindo dunha filiación vangardista, engade elementos moi persoais e intuitivos. O contacto cos ismos chégalle a través da lingua castelá e do galego, mediante a lectura de Manoel Antonio. No ano 1928, publicárase De catro a catro (aínda que algúns dos poemas que forman parte deste libro xa apareceran con anterioridade en diferentes revistas), e o escritor mozo non puido omitir esta homenaxe, esta vez implícita: «Tamén o mar, hoxe, / ten a ialma chea de madureza. / Óuveselle a adolescencia / no vidro do ár / chea de anacos de vísperas / e de intactas navegacións escuras».

Hai neste poema directamente reproducidos varios versos do contido manoelantoniano, como os dous primeiros e o cinco-seis. Mais non están en función do poema de Cunqueiro, senón da homenaxe e solidariedade con esa renovación poética que reafirma no seguinte verso: «Así. Máis alá. Agora da sombra».

Máis alá fora o título do manifesto que no ano 1922 publicaran — seguindo a onda de proclamas literarias do momento- Manoel Antonio e o pintor Álvaro Cebreiro. Cunqueiro, máis dunha década despois, engadíase a todo o que significaba fundamentalmente dentro da lírica do noroeste: ruptura co pasado e renovación estética.

Mais se Mar ao Norde participa, en primeiro lugar, do ambiente literario galego que entón se respiraba, tamén o fai das tradicións lingüísticas, a castelá e a francesa. A primeira, por medio da Xeración do 27 e, en especial, de Rafael Alberti, Jorge Guillén, Pedro Salinas e Gerardo Diego. Alberti e Guillén son os máis visibles en Mar ao Norde. E se o Rafael Alberti de Marinero en tierra ou La amante son os máis recońecibles nos libros neotrobadoristas, e Sobre los ángeles en Poemas do si e non; o Guillén da primeira edición de Cántico, impresa en 1928 pola Revista de Occidente, é unha lectura fundamental. Un ano máis tarde, o mesmo Jorge Guillén, e na mesma publicación, vertería ao castelán «Le cimetière marin", de Paul Valéry, outra das lecturas fundamentais do noso poeta. No prólogo de «Balada das damas do tempo pasado», podiamos ler: «En Francia hai tres poetas cuios apelidos comenzan por $\mathrm{V}$ e son os maiores, conxuntamente con outros tres apelidos que comezan por R. Os primeiros son: Villon, Verlaine, Valéry; os outros, Ronsard, Racine e Rimbaud». En Mar ao Norde ao que máis se achega é a Paul Valéry. 
De todos os movementos vangardistas, Álvaro Cunqueiro na súa primeira aparición pública identificouse co creacionismo e as experiencias plásticas do cubismo.

Do primeiro, coñecendo moi ben os contidos teóricos e a poesía do seu creador, Vicente Huidobro, tomou o cúmulo de imaxes, situacións e conceptos que, como xa escribira o poeta chileno: «Non escatima ningún elemento da poesía tradicional, salvo que nel os ditos elementos son integramente inventados, sen preocuparse en absoluto da realidade nin da veracidade anteriores ao acto de realización». E tamén, como o mesmo Huidobro escribira ao comezo de Horizon Carré: «hai que crear un poema tomando á vida os seus motivos e mudándoos para darlles unha vida nova e independente. Nada anecdótica nin descritiva. A emoción debe de nacer da única virtude creadora». Pero se isto son elementos parciais, aínda que moi definitivos para formar o poema, o que o configura de maneira parcial é a súa descrición da interpretación subxectivista das leis da natureza e a utilización bergsoniana sobre a duración e a simultaneidade temporal. Isto leva a que os poemas de Mar ao Norde teñan remate de orixe e influencias cubistas, sobre todo pola preocupación xeométrica do poema, a disposición espacial dos versos, a medida exacta da palabra. Cunqueiro atendía así algunhas das directrices que Guillaume Apollinaire manifestara no seu traballo Les peintres cubistes, publicado en París en 1913. «O pintor — di Apollinaire- debe ante todo representar a súa divindade [...]. Para iso é necesario abarcar cunha mirada o pasado, o presente, o futuro».

Álvaro Cunqueiro mesturou a visión xuvenil e pura, a experiencia inxenua da paisaxe mariña e terrestre. As formas, as composicións poden ser importadas, mais o material para reelaboralas é absolutamente autóctono: illas, gaivotas, barcos, xanelas, etc. Cunqueiro creou un espazo de seu.

Coa publicación no ano 1933 de Cantiga nova que se chama Riveira, o seu autor eleva á súa máxima consecución o movemento neotrobadorista. En 1957, Cantiga nova reeditábase con seis poemas máis. No ano 1950, incide outra vez con Dona do corpo delgado. Con estes dous poemarios non se remata a faceta neotrobadoresca do poeta, xa que con posterioridade seguirá publicando poemas deste estilo como, por exemplo, «Pero Meogo no verde prado», incluído en Herba aqui ou acolá. A súa facilidade para producir este tipo de versificación puido 
conducilo a un mimetismo do que se liberou grazas a esa permanente conciencia crítica que mantivo sempre para a súa poesía.

As relacións culturais e políticas de Galicia e Portugal ao longo da Idade Media foron manifestas. Pode afirmarse que o nacemento de ambas as dúas literaturas foi paralelo e común. Estas primeiras mostras culturais quedaron recollidas nos cancioneiros medievais que permaneceron practicamente ignorados até finais do século XIX. A "Cantiga de maldizer», de Joan Soares de Paiva, e a "Cantiga da guarvaia», de Pai Soares de Taveiros, son as máis antigas, datadas entre mediados e finais do século XII. Carolina Michäaelis de Vasconcelos divide a lírica medieval galego-portuguesa nos seguintes períodos: a etapa de mediados e finais do século XII; de 1189 a 1245; de 1245 a 1280, a idade de ouro de Afonso X; de 1246 a 1300, o período dionisíaco; de 1301 a 1350, época da decadencia; e a última etapa, desde mediados do século XIV. Outros estudos posteriores reduciron as etapas a catro: preafonsina, afonsina, dionisíaca e posdionisíaca. Dos cancioneiros só se conservan copias dos orixinais, que se perderon na meirande parte dos casos. As tres grandes recompilacións están no Cancioneiro da Ajuda no da Biblioteca Nacional de Lisboa, tamén denominado Colocci-Brancuti; e no da Vaticana. O Cancioneiro da Ajuda foi publicado por vez primeira en París, en 1823, sendo moi reducida a súa edición. Adolfo Vernhagen prepararía outra en Madrid no ano 1849; e a comezos do século xx, daríase a coñecer a edición crítica de Carolina Michäelis de Vasconcelos. Do Colocci-Brancuti e o da Vaticana tamén sairían diferentes edicións entre finais do século xIX e o xx. Mais, como xa comentei, estas edicións tiñan un carácter moi reducido e pasaron bastante inadvertidas até que, en 1928, en Coimbra aparecía o libro de José Joaquim Nunes Cantigas d'amigo dos trovadores galego-portugueses. A conmoción en Galicia foi grande, pois de pronto a literatura en galego atopábase cunhas orixes importantísimas e até entón descońecidas. A poesía galega do Rexurdimento era allea a toda esta tradición escrita e cría que partía de cero, dun idioma por aquel entón aínda considerado dialecto, que ao longo dos séculos sobrevivira grazas aos campesiños e aos homes do mar.

Como di Basilio Losada, o neotrobadorismo veu a ser un fenómeno paralelo ao producido polas edicións de Montesinos das obras de Lope de Vega, Gil Vicente e Juan del Encina, aos que eu engadiría: o Romancero, o cancioneiro de Barbieri, a lírica anónima castelá. $\mathrm{O}$ neopopulismo, en definición de Guillermo 
Díaz Plaja, na súa Historia de la poesía lírica española, é: «...o que interesa aos poetas da linguaxe popular non é, de ningún xeito, o seu ruralismo, a súa grosería, senón o que hai neles de intuición poética, de agudeza lírica, ás veces inconsciente. Interesa tamén a súa lixeireza expresiva, o metro breve...». Este movemento fora promovido polo primeiro Alberti retomando os cancioneiros, e por Lorca, inspirado na tradición oral andaluza; do mesmo xeito que Falla utilizara elementos do folclore nas súas partituras musicais.

No seu prólogo á Escolma medieval galego-portuguesa, de Xosé María Álvarez Blázquez, Rodrigues Lapa afirmaba entre outras cousas: «caso curioso: os poetas que teñen unha intuición divinatoria do fenómeno da arte non esperaron pola crestomatía para deixarse influenciar por ese lirismo. Algúns, e dos máis notables, un Bouza-Brey, un Álvaro Cunqueiro, xa foran beber aos vellos cancioneiros o mel desas flores silvestres, creando unha corrente que poderiamos chamar neotrobadoresca, que se caracteriza pola adaptación das antigas formas, sobre todo o paralelismo, á sensibilidade poética moderna...».

Precisamente, a publicación por parte do profesor portugués Rodrigues Lapa, en 1965, do seu libro Cantigas d'escarnho e de maldizer dos cancioneiros medievais galego-portugueses, mobilizaría outro renacemento desta corrente, máis violenta que as suaves cantigas de amor. Boa parte dos poetas galegos viron nelas unha posibilidade de melloraren esteticamente a súa preocupación cívica.

Fermín Bouza Brey foi un escritor polifacético: xurista, arqueólogo, un dos fundadores e membros máis destacados do Seminario de Estudos Galegos, poeta. Pero ademais foi o verdadeiro promotor e introdutor dos cancioneiros no quefacer da poesía galega. A primeira recreación dese mundo formal, métrico, sensual apareceu no ano 1932, ao publicar Bouza Brey Nao senlleira. Varios anos despois sairía á luz, en 1955, o seu outro único poemario, Seitura, que volvería incidir nos moldes que el mesmo creara. Bouza e Cunqueiro representan ese extraordinario caso de asimilación onde o erudito, o cortesán, o popular e a frescura da súa reactualización animarían ao longo dalgún tempo a lírica do seu país. Mais do mesmo xeito que os ismos e todos os movementos literarios chegaran con certo atraso ao noroeste, o mesmo acontece se quixésemos comparar o neopopularismo dalgúns dos poetas en castelán citados con anterioridade co neotrobadorismo. En 1932, cando aparece Nao senlleira, ou, en 1933 con Cantiga nova que se chama Riveira, os camiños poéticos de Rafael Alberti ou Federico García Lorca eran 
outros. Non hai que esquecer tampouco que xa en Francia (e esta é unha das tradicións literarias máis de Cunqueiro) Verlaine, Laforgue, Maeterlinck, Nerval ou Aloysius Bertrand atoparían a inspiración no popular e nas baladas francesas. Como di Marcel Raymond:

[...] en efecto, un dos méritos dos simbolistas, poetas da alma, é interesarse, despois dos románticos, nas formas artísticas chamadas primitivas e intentar resucitar o espírito das creacións do folclore. Esa corrente de lirismo popular no que un grao de tolemia ao Villon sazona o perfumado recordo dos lays e das endechas, das «cancións históricas» e dos sońos de cortesía (e de picaresca desenvoltura) gracias a Paul Fort, Vielé-Griffin e tamén a Fagus e a Tristan Klingsor, para desembocar en Guillaume Apollinaire.

As cantigas eran cantos de amor (as de amigo) que entoaba unha muller namorada. Sobre as súas orixes hai numerosas opinións que se remontan ao folclórico, pasando polo latino e chegando até o arábigo-andaluz. As cantigas de amigo estaban compostas por unhas cantas estrofas, en xeral dos mesmos versos, repetindo un mesmo tema. Este recurso denominábase paralelismo e case sempre se utilizaba na expresión literaria máis primitiva.

Cunqueiro levou ao esgotamento todos os recursos temáticos e formais do neotrobadorismo. Seguidores como Díaz Jácome ou Xosé María Álvarez Blázquez non atoparían a fórmula da superación, a pesar de que este último foi o creador dun moi interesante libro, Cancioeiro de Monfero. Todos os poetas galegos desta época escribiron cantigas con maior ou menor sorte. Sempre se intentou comparar o neotrobadorismo de Bouza e Cunqueiro. As diferenzas son manifestas, aínda que a súa calidade é moi parella. Fundamentalmente hai algo que os separa. Bouza Brey foi, ante todo, un erudito que empregou esporadicamente este xénero, mentres que Cunqueiro era un poeta capaz de aprender unhas formas e infundirlles unha nova vida. Bouza era máis frío, melancólico, máis remiso a rachar coa forma tradicional e modernizala, mentres que, polo contrario, o autor de Cantiga nova que se chama Riveira deitou sobre este molde estilístico todo o seu mundo de fantasía, as súas outras experiencias literarias, as tradicións orais, mesturándoo con certo aire xograresco máis desenfadado, sen perder profundidade. Ademais, Álvaro Cunqueiro mesturou outros elementos e influencias como, por exemplo, a de François Villon. Moitas veces, achacáronlle facilidade e superficialidade perigosas, mais esta poesía reflicte de novo un estado de ánimo xuvenil, 
un pouco triste pero esperanzado, o desexo do amor vivo a todas as cousas que o rodean, inxenuo e crédulo na bondade natural.

Cantiga nova que se chama Riveira, cuxo contido é practicamente todo de carácter amoroso, naceu da lectura do cancioneiro na edición de Nunes, do primeiro libro de Bouza Brey e das lecturas do primeiro Alberti. Cunqueiro sempre confesou unha grande admiración polo poeta andaluz e aquí concretamente polo seu libro La amante (1925).

Dona do corpo delgado ten varias partes diferenciadas. Concretamente son tres. A primeira sección leva o mesmo título que o libro e ábrese cuns versos pertencentes a un dos sonetos de Shakespeare. Cunqueiro, como novidade, cultiva o verso longo, alexandrino, hendecasílabo e heptasílabo. O neotrobadorismo é aquí un eco afastado que deixa paso ao ubi sunt de Manrique, Villon, Ronsard ou o mesmo Shakespeare. Álvaro Cunqueiro, noutra parte do prólogo a Balada de las damas del tiempo pasado, comentaba: «Ezra Pound, Guillaume Apollinaire, empregaron o ubi sunt preguntando polos seus amigos Billy, Max Jacob, Derain o dos ollos grises coma a alba, cuxos nomes na memoria fanse melancolía...». A segunda parte está composta por dúas elexías, unha das cales é outra homenaxe a Manoel Antonio. A última, chamada "Cantigas do amor cortés» é eminentemente neotrobadoresca. Ten unha cita dun anaco dunha cantiga de Airas Nunes: «Ai estorniño do abelanedo, / cantades vós, e morro eu e peno! / De amores hei mal!».

Mais, pola súa vez, esta pode dividirse en dúas. A puramente neotrobadoresca continúa, como en Cantiga nova que se chama Riveira, a recreación dese efecto de inmobilidade que produce unha intensidade lírica, detendo ao mesmo tempo a posible evolución do poema. E esta segunda está máis mesturada fundamentalmente ao empregar o rondeau. $\mathrm{O}$ «Rondeau das señoras donas pintadas no ouso do vilar, no século XIV, cheirando unha frol» ten como retrouso o verso de Villon «Le temps s'en va!». O «Rondeau da dona enterrada en san Xohan de Badón, con dous anxos aos pés» emprega esta vez como retrouso os versos de Airas Nunes "Quén amores há, / como dormirá?».

O verso de Villon está tomado da «Balada das damas de antano» (título que empregou Cunqueiro para o seu libro de relatos baseados en historias de amores de damas famosas, Baladas de las damas del tiempo pasado), onde o poeta francés amosa o efémero da vida e os seus atributos — como, por exemplo, a beleza- 
preguntándose por damas célebres como Flora, Thais, Eloísa, Berta, Beatriz e un longo etcétera. Cunqueiro tamén emprega maxistralmente esta fórmula.

O rondeau, no século XIII, era unha canción de baile. A súa estrutura musical determinaba a súa forma métrica variable. No entanto, todos os rondeaux teñen de común un refrán de dous a oito versos, colocado ao comezo e repetido dúas veces. O rondeau foi unha forma métrica moi francesa que en España se empregou escasamente ao longo do século XIV. Era unha peza breve de sete a oito versos con dúas rimas.

O surrealismo filtrouse dun xeito moi persoal —como puidemos comprobar na súa especial interpretación dos ismos — na obra poética de Cunqueiro. Reflíctese dunha maneira máis clara en Poemas do si e non. Pode dicirse que este poemario foi o introdutor do surrealismo na literatura galega, onde tampouco tería salientables representantes. Paul Éluard exerceu unha influencia ostensible, pero de novo volvemos atoparnos co único Manoel Antonio coñecido naqueles tempos, o De catro a catro, e a través del chegamos a unha das súas fontes, Vicente Huidobro. Precisamente, o poema titulado "Limiar", co que se abre Poemas do si e non, é herdeiro directo e sucinto do "Prefacio» co que o poeta chileno presentaba, en 1931, Altazor. As referencias directas a Manoel Antonio corresponden neste poema a versos tales como:

Aínda colgaba do aramio da anteguerra todas as

intactas maravillas inauditas.

[...]

pra atopar a indefinición das súas craridades navegantes

[...]

pra acenar polas súas perfebas de fume

os panos enloitados da cocińa.

O libro, que para o profesor Ricardo Carballo Calero leva este título baseado no sic et non de Pedro Abelardo, aínda que o mesmo autor non corroboraba isto explicitamente, está dividido en tres partes: «Ela, El, Ela e El». Esta última ten outra sección denominada «Noivados». Todo o libro, a excepción deste fragmento, ten dous puntos de partida. Por un lado, Capitale de la douleur, libro de Paul Éluard, publicado en 1926; e Sobre los ángeles, de Rafael Alberti. "Huésped de las nieblas», verso de Gustavo Adolfo Bécquer, é a sección de Sobre los ángeles 
máis próxima a Poemas do si e non. En Capitale de la douleur, hai un poema que considero interesante citar para comprender en boa parte o significado do libro de Cunqueiro. «L'amoureuse» é o seu título:

Elle est debout sur mes paupiers

Et ses cheveaux sont dans les miens,

Elle a la forme de mes mains,

Elle a la couleur de mes yeux,

Elle s'engloutit dans mon ombre

Comme une pierre sur le ciel.

Elle a toujours les yeux ouverts

Et ne me laisse pas dormir.

Ses rêves en pleine lumière

Font s'évaporer les soleils,

Me font rire, pleurer et rire,

Parler sans avoir rien à dire.

«Noivados» son poemas máis autónomos. Na maioría dos casos actúan de contrapunto. Poemas do si e non é un libro desesperanzado. A soidade do amante non procura á amada para que xunto con ela desapareza esta sensación angustiosa, senón, polo contrario, o encontro coa amada significa a unión de dúas soidades que forman unha soa, mais sen fusión. Outra das claves de Poemas do si e non escóndese no poema titulado «Parque». Individual e colectivamente a parella sitúase dentro dun ámbito pechado, dentro dun orbe que zumega a nostalxia do paraíso-xardín-parque perdido.

A soidade, o fracaso determinista en atopar esa felicidade é algo orixinal que lles foi alleo, e que contemplan como algo irremediable. A ficción de crear un Paraíso establécese coa formación dese mundo fantasiado que van facendo e desfacendo os amantes. Un lugar terreal-artificial que devolve a imaxe do perdido. Poemas do si e non remata precisamente cunha elexía, un canto de rememoración e dun novo fracaso da reconstrución. Pode reproducirse o Paraíso perdido na terra mediante o amor? A soa ficción de Paraíso terreal para dous? Evidentemente xa comprobamos que Álvaro Cunqueiro é pesimista. Volvendo ao poema «Parque», nos seus tres últimos versos atopamos certas respostas: 
Noiturno amante en rocas sin aramios:

Dobre parque valdeiro dobre parque

Igoal vidro agobiado en luz fundida.

Todo este poemario é un monólogo interior a dúas voces. Isto sérvelle ao poeta para captar as esferas irracionais do sentimento e aqueles outros espazos da razón enfrontados co non dito, co baleiro, co silencio, co espazo interlineal. Aínda cando está poetizando en terceira persoa, este monólogo enfronta o poeta consigo mesmo.

Herba aqui ou acolá cando, no ano 1980, aparecía recollido no Tomo I. Obra en galego completa, marcaba o punto máis elevado dun poeta que estivera sempre no fío da modernidade, aínda sen pretendelo, en cada unha das súas entregas, ofrecendo unha moi alta interpretación e unha esmerada orixinalidade creadora.

Miguel González Garcés recollía para publicar (aínda que este tomo non apareceu xamais por separado, sendo esa a primeira vez) unha longa serie de poemas que Álvaro Cunqueiro escribiu ao longo dos seus últimos vinte anos. A meirande parte viran a luz — con máis ou menos variacións — en diferentes publicacións. Se en case todos os seus libros anteriores, tanto en castelán como en galego, estaba presente o tema do efémero, da pasaxe do tempo, en Herba aqui ou acolá existe xa un enfrontamento directo coa morte, o temor ante a súa chegada inminente, que o poeta presenta e simboliza a través de diferentes recordos — persoais e históricos- enmarcados no devir das estacións.

Mais o poeta-home confía na permanencia terreal e na resurrección da carne. A primeira realízase por medio da obra literaria, que sempre sobrevive ao seu autor como outra alma desprendida dese mesmo corpo. A outra, dun xeito panteísta e cíclico do eterno retorno. Da mesma maneira que a natureza renace cada primavera, o corpo do poeta unido xa ao caos primixenio crece de novo.

Neste último libro hai varias tendencias. Unha ampla dedicada á recreación de mitos clásicos, de lendas e historias xa contadas ou reinventadas. Estas recreacións de personaxes históricos e culturalistas abundan en toda a súa narrativa: o ciclo artúrico, Merlín e familia; o ciclo bretón, As crónicas do sochantre; o mundo clásico, Un home que se parecia a Orestes; o mundo árabe das mil e unha noites, Si o vello Simbad volvese ás illas; o Renacemento, Vida e fugas de Fanto Fantini. Moitos dos poemas englobados nestes grupos foron escritos paralelamente a estas e outras novelas que non foron citadas. Por exemplo, «O retorno de Ulises» ía ser 
o título dun só poemario que xamais foi concluído. A súa formación levouna a cabo mentres escribía As mocidades de Ulises. «Os setenta pavillós», «Unha canción foi prohibida no Sur» e «Os catro chefes da Casa Gingiz» fórono cando redactaba Si o vello Simbad volvese ás illas, para incluílos tamén noutro volume. Por último, o grupo de poemas que leva o título «Eu son...» (Danae, Paltiel, Edipo e Dagha) compoñían un distinto libro que debía de titularse Eu son.

A outra tendencia é a máis lírica, manifestando o poeta esas preocupacións existenciais. Aquí é onde a identificación do creador é tal que produce moitos dos mellores poemas da lírica galega, inmediatamente equiparables a calquera tradición lingüística e literaria. Thomas Stearns en The west land, así como Ezra Pound e W. B. Yeats. Pero aquí, máis que nunca, Álvaro Cunqueiro volve demostrarnos que el sempre supera amplamente as súas lecturas. «Deica abril», "Acolá están as illas», «Retrato: Cabeza de home de Antonello de Mesina», «Lor Dunsany/Epitafio», "Un poeta esquece os días de chuvia», «O poeta escolle abril», «Un home que desperta», «Alma, coma no concerto», «Herba aquí ou acolá» ou "Ese alguén de meu que nunca volve» son poemas escritos por un mestre que ten moito que dicir e que, ademais, dispón dos medios expresivos (nun idioma até daquela pouco acostumado ás dilatacións) para pońelo en práctica.

Unha última manifestación que aquí aparece como algo illado e anacrónico, mais, como xa dixen anteriormente, Álvaro Cunqueiro resístese a abandonar, é o neotrobadorismo. "Pero Meogo no verde prado» é o último e belísimo poema que, simbolicamente, pecha o ciclo dos libros Cantiga nova que se chama Riveira e Dona do corpo delgado.

Cunqueiro sentiu sempre unha intensa preocupación pola palabra e o mundo autónomo que nela se pecha. A palabra é unha das chaves para estar máis próximo ao Paraíso, axuda a crear a súa ficción. O autor de Merlín e familia, como o inesquecible Aloysius Bertrand de Gaspard de la nuit, con quen ás veces podería establecerse un símil literario pois cumpre moi de preto coas características que Charles Baudelaire lle aplicou: «o milagre dunha prosa poética, musical, sen ritmo nin rima, o bastante flexible e o bastante contrastada como para adaptarse aos movementos líricos da alma, ás ondulacións da fantasía, aos sobresaltos da conciencia...», vive a escritura como a súa única vida.

Estou seguro de que Álvaro Cunqueiro desexou escribir un libro ao estilo de Gaspar de la nuit. En vez de ser Dijon o núcleo local de referencia, este sería 
Mondoñedo. De feito, levouno a cabo de xeito parcial, en maxistrais anacos na súa obra narrativa. As primeiras lińas do Gaspar resumen tamén o pensamento e a sensibilidade de Cunqueiro: «Amo a Dijon como o neno á ama de cría cuxo leite mamara, como o poeta á moza que iniciou o seu corazón. ¡Infancia e poesía! Que efémera unha e que enganosa a outra! A infancia é unha bolboreta que corre a queimar as súas brancas ás nas lapas da xuventude, e a poesía é semellante á amendoeira: as súas flores son aromáticas e os seus froitos amargos».

«Os oficios de Bran». Álvaro Cunqueiro traduciu ao galego (Faro de Vigo, 2 de maio de 1971) un fragmento de The voyage of Bran, "A navegación de Bran, fillo de Febal», publicado e comentado por Alfred Nutty Kuno Meyer. Jean Markele, un dos principais investigadores do mundo celta, opina que quizais san Barandán sexa unha cristianización de Bran. Markele, en La epopeya celta en Irlanda, conta como nunha ocasión, en que o heroe Bran e o seu exército se atopan diante dun río que non poden cruzar, Bran déitase sobre el (é una especie de xigante) e fai pasar os seus homes sobre o seu corpo, pronunciando as palabras que Cunqueiro retoma en galego: «QQue o que é chefe sexa ponte!». Robert Graves en La diosa blanca refírese a Bran como o deus que tiña un alfabeto secreto «antes de que Gwydon, coa axuda de Amathaon, o roubase na Batalla das árbores». Álvaro Cunqueiro mestura neste poema toda esa armazón mítico-céltica da que procede parte da cultura do seu país, coa non menos importante do Mediterráneo. «iAnimula, vagula, blandula!» pertence á Vita Hadriani (atribuída a Elio Espartiano). O verso fora empregado posteriormente como leitmotiv por outros poetas. Entre nós, Ramón María del Valle-Inclán e Luis Cernuda, autores polos que o mindoniense sentía gran devoción. Do primeiro, ademais, era familiar.

«Ricorditi di me». No poema «Deica Abril», di o autor nos seus primeiros cinco versos:

Quitando a pucha direiche

Deica as rosas que veñen!

Carlota, Ofelia ou Pía

Sexa un destes o teu nome ou outro,

Deica as rosas que veñen! 
Pía é precisamente a personaxe anónima con quen Álvaro Cunqueiro xoga noutro poema, «Ricorditi di me», título que fai referencia aos últimos versos do «Canto v do Purgatorio» da Divina Comedia de Dante:

De cuando tu sarai tornato al mondo,

E riposato della lunga via

Seguitò il terzo spirito al secondo,

Ricorditi di me che son la Pía:

Siena mi fe, disfecemi Maremma:

Salsi cuoli che'nnanellata pria

Disposando m'avea con la sua gemma.

Pía Guastelloni foi viúva dun Tolomei, despois casada con Paganelo Panochieschi, quen a fixo encarcerar no seu castelo de Maremma, onde lle causou a morte. En «Ricorditi di me», omítese a referencia ao primeiro matrimonio e preséntase a Pía morta polos celos de Nello: «Disfemmi la Maremma. Púxome Nello dei Paganelli na punta dun coitelo, coidando que eu non era virxe».

Outros versos son moi interesantes para afondar aínda máis na pequena grande historia deste interesante poema: "Cortado fun antes de tempo / eu que quixen ser lirio e pasei por puta / e o que sabía de bicar era por libro». Este aprende a «bicar por libro» líase en obras como o Ars amandi, de Ovidio, as versións de Tristán e Iseo, o Tratado de amor de Andreas Cappellanus, Lancelot de Chrétien de Troyes, etcétera. A lírica de amor toscana do século xiII reflicte como arquetipo de amante a este personaxe fundamental da Táboa Redonda do rei Artur. Dante considérao máis importante que Tristán, pois Francesca de Rimini e Paolo namoráranse lendo este libro:

Noi leggiavamo un giorno per diletto

Di Lancialotto come amor lo strinse:

Sole eravamo e sanza alcun sospetto.

Per piú fíate li occhi ci sospensi

Quella lettura, e scolorocci il viso,

Ma solo un punto fu quel che vi vinse.

Quando leggemo il disiato riso

Esser baciato da cotanto amante.

Questi, che mai da me non fia diviso, 
La bocca mi bacio tutto tremante.

Galeotto fu il libro e chilo scrisse:

Quel giorno più non vi leggemmo avante.

Así aparecen no "Canto v do Inferno», onde os colocou Dante, na Divina Comedia. Francesca era filla dun amigo de Dante, Guido da Polenta de Rímini. Fora casada no ano 1275 con Gianciotto, fillo de Malatesta de Rímini. Mais ela mantivo os amoríos co irmán menor do seu marido, Paolo, tamén desposado por un compromiso de Estado. Foron asasinados dez anos despois do matrimonio de Francesca, polo seu marido e, ao mesmo tempo, irmán.

Stendhal, nos seus Paseos por Roma, refírese tamén á triste pasaxe de Pía. O novelista francés fala da normalidade coa que, ao longo de varios séculos, se envelenaba á xente. A historia de Pía compáraa coa mesma sorte que correu Desdémona. Nello, despois de casar con Siena, alimentado polos celos (que segundo Dante non eran fundados), levouna á marisma de Siena, famosa entón polos efectos da aria cattiva. Xamais quixo dicirlle á súa desgraciada esposa a razón do seu exilio. O orgullo de Nello non lle permitiu pronunciar queixa nin acusación. Vivía só con ela, nunha torre abandonada, cuxas ruínas ao carón do mar visitei; non rompeu xamais o seu desdeñoso silencio, xamais respondeu ás preguntas da súa nova esposa, xamais escoitou os seus rogos. Esperou friamente ao seu lado que o aire pestilente producise os seus efectos. Os vapores da marisma non tardaron en murchar os seus trazos, os máis fermosos, dicíase, que neste século se ollaran na terra. Pía morreu en poucos meses.

«Deica Abril». Quedan por desentrañar outras dúas personaxes femininas deste poema: Carlota e Ofelia. Esta última refírese, sen dúbida, á Ofelia de Hamlet, amante tráxica. Mais Carlota pode referirse —ocórreseme nun principio- ou ben á exaltada xirondina Carlota Corday, asasina de Marat, ou a Carlota, emperatriz de México, esposa de Maximiliano de Austria. Antes da execución do seu esposo, xa evidenciara probas de tolemia. Por el intercedeu en persoa ante Napoleón in e o Papa Pío IX, sen resultado positivo. O escritor mexicano Fernando del Paso ten unha novela sobre este asunto: Noticias del Imperio. Despois deses tristes acontecementos, estivo confinada en Austria e logo no castelo de Bouchout. No entanto, hai unha terceira Carlota que eu creo que si é a verdadeira. A Carlota de Werther, de Goethe. En resumo, varias personaxes femininas marcadas por amores desgraciados. 
As referencias a personaxes e situacións relacionadas coa Divina Comedia son permanentes na obra poética de Cunqueiro, así como en parte da súa narrativa. De Dante chegou a escribir:

É o maior poeta, aquel para quen o fuxidío e maleable instrumento palabra foi máis de seu. Para min hai pasaxes imborrables. Léoos en alto con esta pronunciación siciliana que teño e que me vén de familia (a mińa bisavoa era italiana, Barcino Vicetto de Mesina, e a mińa avoa, dona Carmen Montenegro, falábame de rapaz nun siciliano nervioso e entrecortado, menos doce que o toscano que escoitei despois, máis delicioso). A Divina Comedia, como se sabe, estivo a piques de ser escrita en catalán, e non o foi por cuestións políticas e temporais: aos seus inimigos toscanos púxoos Dante en toscano no Inferno. Con todo, hai os tercetos cataláns da Comedia, inesquecibles. Dante atopa no purgatorio a Arnaldo Daniel, un dos grandes trobadores, e pregúntalle quen é: «io so Arnau que plor i vai cantán. Considerós la passada folor...». Se o Dante escribise en catalán a Divina Comedia, ninguén podería evitar unha Cataluña independente e soberana.

«Eu son Danae». Está unida ao mito de Perseo. O rei de Argos, Acrisio, fora avisado por un oráculo de que sería asasinado polo seu neto. Ante semellante nova, Acrisio pechou a súa única filla, que era Danae. Xúpiter, namorado dela, transformouse en chuvia de ouro e penetrou na torre onde estaba custodiada. Desa unión naceu Perseo. Nai e fillo, expulsados fóra do reino, foron parar aos dominios do rei Polidecto. Tras as loitas deste heroe coa Medusa e outras conquistas bélicas, entre as que se conta a vitoria sobre o seu tío avó que destronara ao seu cruel avó, veu a reconciliación. Mais nos xogos que a festexaban, Perseo lanzou o disco con tan mala sorte que se cumpriu a predición do oráculo.

«Eu son Paltiel». Neste poema refírese a II Samuel, 3, 14. Esta pasaxe conta a guerra civil entre a casa de David e a de Saúl. David pediu que lle devolvesen a súa primeira esposa, que xamais repudiara e pola que seu pai pagara unha gran cantidade de cartos. Esta era Micol, «adquirida ao custo de cen prepucios de filisteos", e que agora se atopaba casada con Paltiel, fillo de Lais. Segundo conta a Biblia, Paltiel seguiuna chorando até Bajurim. Esta personaxe desapareceu e o poeta quéixase do breve tránsito de tan desgraciado amante: «Non entendo por que Yahvé quixo / que a miña historia quedase para sempre / coas miñas bágoas de Bujarim, en II Samuel 3, 14, / desesperadas. / E aínda para algún pasarei por 
cornudo!». Na cabeza de Álvaro Cunqueiro tamén está implícita a lembranza da Micol de $O$ xardín dos Finzi Contini, de Giorgi Bassani.

Saúl entregáralla a David como unha trampa. Mais, cando os soldados do seu pai intentaron matalo, atopárona a ela no leito xunto cun boneco de trapo.

«Recoñecemento de Harold Godwinson». Ao regresar dunha viaxe que fixera alá polo ano 1966, acompañado por Francisco Fernández del Riego, foi cando Álvaro Cunqueiro publica no Faro de Vigo os Cantos de Hastings ( A chegada das naves», "Harold dice adeus a Edith», «Monólogo de Edith», "Harold no campo de batalla» e «Morte do cabalo de Harold Rei»). O conxunto de todos eles deu lugar ao «Recoñecemento de Harold Godwinson». Cunqueiro comentaba nunha breve nota introdutoria que, finalmente, fixera aquela viaxe tan sońada aos outeiros de Hastings en Inglaterra. O lugar exacto onde se produciu tan sanguento encontro chámase aínda hoxe The Battle. Unha pedra conmemórao.

Harold Godwison naceu no ano 1022. Morreu en 1066. Era fillo do conde de Godwin de Essex, quen combatera contra a presenza normanda en Inglaterra. O seu fillo casara coa viúva do rei de Gales derrotado por el, e foi coroado tras a morte de Eduardo o Confesor. Con motivo deste acontecemento, comezaron as disputas. Guillermo o Bastardo de Normandía declaroulle a guerra. Foi derrotado e morto na batalla de Hastings. En «Recoñecemento de Harold Godwinson» fálase de Edith Swanehals ou, como aparece escrito noutros sitios, Schwanenhals. Edith era a amante de Harold, que tivo que abandonala para aumentar así os seus dominios mediante o matrimonio coa viúva do seu inimigo. De aquí é de onde parten moitas das lendas e argumentos literarios urdidos sobre tan sanguento final. Harold, debido á súa ambición e á súa falta de fidelidade amorosa, foi castigado coa derrota, mentres que Edith lle permaneceu fiel buscándoo entre os cadáveres polo campo de batalla. Outra das versións refírese ao motivo polo cal Guillermo de Normandía lle declara a guerra. Harold prometéralle a sucesión ao trono, e este xuramento roto provocaría a loita.

Álvaro Cunqueiro non se detén en analizar os motivos de Estado, senón que se inclina polas interpretacións románticas. Recréase na paisaxe posterior á batalla e fai xirar o poema arredor da amante fiel até a morte: «A derradeira carícia de Edith foi aquel calado tecer / perto do morto, e cando saía a lúa / misturou fios azúes da luz da viaxeira cos seus». 
«Un retrato de desconocido, un epitáfio e outros personaxes». A lista destes podería ser aínda maior, malia que moitos deles son creados pola imaxinación do poeta e, polo tanto, de moi difícil explicación histórica ou literaria. No grupo de poemas do ciclo árabe, era inevitable a presenza de Sherezade e Harun-al-Rashid, o heroe de tantas pasaxes de As mil e unha noites, califa abasí que viviu do 766 até o 809 .

No libro Dona do corpo delgado hai varias referencias a Airas Nunes. En Herba aqui ou acolá, Álvaro Cunqueiro dedícalle un poema a Pero Meogo, «Pero Meogo no verde prado». Ambos foron dous dos máis importantes trobadores. Airas Nunes tiña procedencia galega e, segundo semella, era clérigo. Asistiu á peregrinación de san Fernando e colaborou co rei Afonso x nas Cantigas de Santa María. As cantigas de Pero Meogo están cheas de cervos, de aí as referencias de Álvaro Cunqueiro. Tamén outras referencias moi eróticas reiteradas polo xograr son retomadas polo noso poeta: «Dime a onde vai o teu cabalo, doncela, / dime a onde vai, polo meu amor! / Vai pra unha fita verde de seda, / meu cazador».

«Retrato: Cabeza de home, de Antonello de Messina» e «Lord Dunsany / Epitafio» son dúas pequenas xoias poéticas que merecen tamén unha parada moi especial.

O pintor siciliano do século xv Antonello de Mesina deixou moitos retratos de homes posteriormente anónimos. Descońezo cal é a cabeza do home sobre a que Álvaro Cunqueiro poetiza, e mesmo se o poeta se refire a algún dos retratos que pasan por ser autorretratos de Antonello. Sexa quen sexa, o autor de «Retrato: Cabeza de home, de Antonello de Mesina» quedou fascinado pola expresión destes rostros que se cońecen como eternos ante quen os contempla: «...Búlrase / dos séculos e dos anxos, e de todo / o que non dura, porque el é eterno».

«Lord Dunsany / Epitafio» é a homenaxe póstuma ao escritor irlandés Edward John Moreton Drax Punkett, décimo oitavo barón Dunsany, nado en Londres no ano 1878 e falecido en 1957. Era un aristócrata irlandés vinculado co condado de Meath, próximo a Dublín. Loitou na guerra anglobóer e na Primeira Guerra Mundial, na que resultou ferido. As súas orixes remóntanse a Henrique II e ao asasinado Thomas Becket. O seu título nobiliario creárase no ano 1439. Nos dominios do condado de Meath atópase Tura, unha fortaleza que foi destruída durante un ataque de Fingal, quen creou o señorío do seu nome xunto co de Dunsany. Tura foi reiteradamente citada por J. Macpherson nos poemas de 
Ossian e por J. Smith en The fall of Tura. "Unha noite na taberna» é un espléndido relato que incluiría Jorge Luis Borges, Silvina Ocampo e Adolfo Bioy Casares na Antoloxía da literatura fantástica.

Lord Dunsany foi un intenso cultivador desa literatura e un autor eminentemente imaxinativo que retomou moitas historias populares, ás veces dándolles tinturas macabras. Tamén sobresae a súa actividade como autor teatral. $\mathrm{O}$ seu primeiro libro de narracións, que o deron a coñecer, foi The Gods of Pagana. «E no camiño de Carcasona saudábano / os que endexamais chegarían acolá». Estes dous versos do poema a Lord Dunsany fan referencia a un dos máis misteriosos contos do autor irlandés, aquel que precisamente se titula «Carcasona». Este relato comeza coa seguinte introdución: «Nunha carta do meu amigo a quen xamais vin, un dos que len os meus libros, aparecía citada esta lińa: "En canto a el, xamais veu a Carcasona". Ignoro a orixe da lińa, mais fixen este conto sobre ela».

Dunsany sempre nos fala de: fantasmas, fadas, camiños que adquiren vida e non nos conducen a parte ningunha, seres e obxectos invisibles, vagabundos misteriosos, guerreiros, cidades inexistentes ou inexpugnables, etcétera. Elementos todos moi caros para o autor de As crónicas do Sochantre. A obra de Dunsany é comparada coa de Blake. A este respecto Borges matizou que había unha diferenza esencial: «A de Blake corresponde a unha renovación total da ética, que procede de Swedenborg, e que Nietzsche prolongará; a de Dunsany, a un libre e gozoso xogo da imaxinación». Unha imaxinación cuxa materia prima, moitas veces, procedía (como tamén en Cunqueiro) da tradición oral campesiña do seu condado irlandés. En Na miña Irlanda, Dunsany escribiu: «non falo nunca das cousas que vin, senón das que soñei».

Álvaro Cunqueiro sempre estivo — sen que fose esa a súa intención— na vangarda poética (neotrobadorismo, surrealismo...). Na narrativa foi á contra do seu tempo e tamén por diante. Relanzou a imaxinación, o fantástico e o onírico, algo que ao longo dos últimos séculos estivera moi lonxe da meirande parte da literatura en castelán, non tanto na recente galega. Mais engadiría que cos poemas recollidos en Herba aqui ou acolá, ademais doutros moitos publicados en diferentes xornais e revistas ao longo dos seus últimos trinta anos, adiantouse ás tendencias renovadoras e culturalistas que rexurdiron na poesía española durante os anos finais da década dos sesenta. 
Nunha das miñas últimas visitas a Álvaro Cunqueiro no seu piso de Vigo, observei que tiña entre os seus obxectos mais prezados unha pequena bóla de cristal. Era un deses artefactos que, ao darlle a volta ou, sinxelamente, ao xiralos, inúndanse de falsas folerpas de neve. Estas caían sobre a silueta dunha antiga cidadela amurallada, recreada con diferentes cores brillantes. Era Carcasona.

Cunqueiro contoume que adquirira tan prezado tesouro nunha viaxe feita en compañía de dous dos seus mellores amigos e máis admirados compañeiros de letras: Joan Perucho e Néstor Luján. Cunqueiro acariciábaa coma un mago.

Poucas semanas despois de que o escritor galego falecese, atopeime percorrendo a rexión cátara. Lembraba un verso do epitafio que este lle dedicara a Lord Dunsany: «E no camiño de Carcasona saudábano / os que endexamais chegarían acolá»; así como dalgúns fragmentos que o escritor irlandés escribira ao redor da cidade medieval gala: «Esta cidade é a mais bela das marabillas da mañá; o sol racha en alaridos cando a contempla; por Carcasona, a tarde chora cando a tarde morre». Finalmente, chegamos nun solleiro e solitario atardecer invernal. A cidade estaba alí, inmersa en si mesma, maxestosa. Tanto me impresionou a súa mestura de verdade e falsidade, á que non pouco contribuíu a reconstrución realizada no século pasado por Violet-le-Duc, que desde entón roldou pola miña cabeza a idea de escribir un poemario tendo como eixe central semellante escenario teatral. A pesar de redactar varios poemas (incluídos en Derivas), quedou inconcluso, fragmentario. En realidade, tal como vin a cidadela.

En Carcasona, nunha tenda de regalos, atopeime cun só tipo de bóla de cristal. Non era a mesma que vira. No entanto, decidín mercala unha vez finalizada a visita. Tanto nos demoramos polas murallas, patios e pasadizos que, ao saír, o local xa estaba pechado.

De regreso a España, despois de estar nas soidades de Queribus, Lastour ou Peyrepertuse, co zunido terrible daquela frase de Simon de Montfort: «Tuez-les tous, Dieu reconnaîtra les siens», pasei de novo por Vigo. César Cunqueiro trasladara á súa casa parte da biblioteca e algúns outros obxectos persoais que non foron enviados a Mondoñedo. Nunha repisa atopábase unha bóla de neve que non era a mesma, mais que seguía tendo como motivo principal a cidadela fundada polos romanos. César contoume que a que eu vira a rompera un dos seus netos norteamericanos. A perda deste Rosebud sumira en tal tristura ao autor de As crónicas do Sochantre, por aquelas datas xa afectado da enfermidade, que telefonaron 
a Perucho e a Luján por se algún deles podía achegarse até ese punto xeográfico do sur de Francia e comprala de novo. Non sei cal deles o fixo, mais o caso é que Cunqueiro puido morrer contemplando unha das súas cidades invisibles.

Lembrando esta historia, compuxen un pequeno poema, «Bola de nieve»: «Te sostengo grano, boya, esponja, yelmo, nimbo, estanque transparente, / osamenta vacía, tregua de vidrio quebrado. / Y al girar / caen copos en muchos rincones / de este lugar tan fértil. / Frutos antropomorfos / penden entre los tréboles, / como las grandes ciruelas que se ven en Tours».

Eses «froitos antropomorfos» puideron ser algúns dos aforcados que atopou, o tan querido para Cunqueiro, François Villon camiño dos seus varios desterros, quizais el mesmo? 